\title{
NARRATIVES ABOUT WORK IN CROATIAN \\ CELEBRITY CULTURE
}

\section{OZREN BITI}

This paper is based on research into narratives surrounding the work of (micro)celebrities in Croatia. The analysis comprises written materials dedicated, in various degrees, to different aspects of work as it is performed in Croatian celebrity culture, such as space, time, intensity, character, and value of the work in question; published in newspapers and weeklies or posted on web portals during 2018 and the first half of 2019. Micro-celebrities occupy a special place within celebrity culture, characterized not only by lesser fame and public recognition compared to traditional celebrities, but also by different avenues leading to the acquisition of this particular status.

Keywords: celebrity culture, micro-celebrity, influencer, work, media narratives
Prispevek temelji na raziskavi pripovedi o delu "mikro-slavnih" oseb na Hrvaškem. Raziskava analizira tekste, objavljenev casopisih, tednikih in na spletnih portalih v letu 2018 ter prvi polovici 2019, katerih predmet so različni vidiki in pogledi na delo v hrvaški kulturi slavnih: prostor, čas, intenzivnost, pomen, navsezadnje vrednost. Mikro-slavni imajo posebno mesto v kulturi slavnih. Zanje je znacilno, da nagovarjajo specifične ciljne skupine ter so deležni ne le manjšse slave in javnega priznanja, temveč si ju tudi pridobijo po drugačnih poteh, č jih primerjamo s klasičnimi« slavnimi osebnostmi. Ključne besede: kultura slavnih, mikro-slava, vplivnež, delo, medijske pripovedi

\section{INTRODUCTION}

\section{HOW MIGHT OUR GRANDPARENTS PERCEIVE INFLUENCERS?}

In November 2018, editor and host of the late-night TV news magazine "RTL Direkt" Zoran Šprajc interviewed 28-year-old Ella Dvornik, granddaughter of famous Croatian actor Boris Dvornik and daughter of popular singer Dino Dvornik. Ella herself gained media fame in an RTL reality show featuring the daily life of her family, Dvornikovi (The Dvorniks), broadcast on television in 2006 and 2007. Later on, she successfully recaptured public attention as a blogger and influencer.

In the above show, this latter claim to fame was the topic of conversation. At one point the host inquired: "OK, so what is influencing all about, in short?", following up with the comment: "My grandmother, some other folks perhaps, might call it 'money for nothing'. You take pictures, selfies ... and it pays well." The young lady's reply was: "If that's what people are willing to pay for ... As my own grandma says, there's a buyer for every product."'

1 https://www.rtl.hr/tv-novosti/najave/3292133/ella-dvornik-dosla-u-rtl-direkt-poduciti-zorana-sprajcasto-je-to-zapravo-influencer/ (accessed on 12 July 2019). 
Figuratively speaking thus, even grandmothers are playing their part in the public polemic concerning the meaning and value of such heavy involvement in social networks and social media. In addition to perpetual posing, story-telling and picture-taking, this involvement usually implies not only a sizeable number of followers who are interested in photographs and other lifestyle posts, but also the interest of various companies and brands looking for new advertising platforms. All things considered, for successful influencers, a respectable living from combined activities across social networking sites and exposure channels is currently possible. ${ }^{2}$

However, even when stripped down to the mechanics of supply and demand, controversy remains about whether there is any aspect of the influencer's labour that implies effort and energy expansion. How, then, to bring these legacy viewpoints closer together, i.e., how to reconcile the logic of the "culture of work "with the logic of "culture of capitalism"? The public has a variety of parameters that may be instrumental for expert assessment and scientific discussion concerning the economic, even the ethical dimensions of this activity, or rather this work/occupation.

It is worth exploring what makes this particular, digitally-mediated will to seek attention and gain public recognition/influence - so as to convert it into economic capital - conceptually new or substantially different, by any measure, from the pre-existing ways of monetizing fame. To pursue the topic of influencers in this respect means to focus on micro-celebrity in a broader sense, or even celebrity culture as a whole; moreover, it means taking into consideration different and yet similar forms of what it is like to be famous and live with fame in the $20^{\text {th }}$ and $21^{\text {st }}$ centuries. Furthermore, reflecting on the work of influencers in Croatia today requires not only attention to the local media and media policies and specific features of the Croatian celebrity culture, but also an overarching view of the phenomenon given the transformation of (the value of) work in post-transitional Croatia.

\section{THEORETICAL CONCEPTS}

\section{CELEBRITIES}

Not particularly long ago, it used to be taken for granted that famous, high-profile public persons originate from the spheres of film, music, or sports. The "fame culture" as a concept, tied first to the advent of the press, then to movies and photography, then to radio and television, has been expressing itself for the past 200 years or so. "The society of the spectacle" that began to emerge in the $20^{\text {th }}$ century slowly turned "famous people" into

2 For more information on the follower counts and earnings of the most popular female Croatian influencers, see e.g. https://slobodnadalmacija.hr/novosti/biznis/clanak/id/559597/koliko-mogu-zaraditihrvatske-influencerice-slucajna-objava-sonje-kovac-pokazala-je-da-se-radi-o-svotama-o-kojima-prosjecni-hrvat-moze-samo-sanjati, accessed July 12, 2019. The data fluctuates across time. 
celebrities. The state of the matter (of media landscape) was further complicated when the media took interest in political figures and vice versa, and even more complex with the rise of so-called reality television and new mobile media, which enabled "ordinary people" to achieve relatively large "stardom".

The majority of traditional celebrities do not live ordinary, conventional lives and, by virtue of their exceptionality, embody a certain social type, promoting particular behaviour patterns, even models of consumption. Although celebrities largely share this trait, they differ significantly in other characteristics, reflected primarily in the way in which they attain their status. According to Rojek (2004: 17-20), "[C]elebrity status comes in three forms: ascribed, achieved, and attributed." All celebrities, from the members of royal families to athletes to Big Brother participants, require visibility in order to maintain their celebrity status. They need exposure, the attention of the public gaze (an elevated media profile) (Cashmore 2006: 10). In doing so their private life generally attracts much more attention than their professional one (Turner 2004: 8).

In the broadest sense, the phenomenon of "celebrity" may be explained as a symptom of significant cultural and media changes taking place over the past several decades under the influence of globalization (see Turner 2004: 31-34). After all, it is not a coincidence that dedicated research into famous public figures, collectively referred to as "celebrity studies", developed 20 or so years ago as a specific research branch at the junction of cultural studies and media studies. On the scientific map, this research area set itself at the intersection of sociological and cultural-anthropological interest in the current social forms of consumption and spectacle.

Among the most prolific authors in this research niche are Chris Rojek, Graeme Turner, and Ellis Cashmore. For the past 20 years, all three have actively followed the development of the celebrity phenomenon. Although some of their definitions of celebrities have been brought into question, the theses and typologies they offered are still in use. ${ }^{3}$ There is no comparable socio-humanistic research with a serious and lasting focus on the topic of celebrity in Croatia, but the work of Hajrudin Hromadžić on media culture (Hromadžić $2010,2013)$ partly touches on the problematics of celebrities.

\section{CELEBRITY CULTURE}

Even if we should disagree with Ellis Cashmore's provocative statement that "celebrities are the least important element in celebrity culture" (Cashmore 2006: 1), or should not consider his position on this culture in a broader sense entirely well-founded, we shall for the purpose of this paper nevertheless look beyond the phenomenon of celebrity, drawing on Cashmore's idea of "celebrity culture" as having the paramount conceptual importance

3 In this frame it is necessary to mention authors from Hungary, Slovenia, and Serbia, dealing with: heroes and celebrities typology (Povedak 2014), with bubble celebrities (Podjed 2014, 2016), and with "marginal people" (Čolović 2014). 
as a framework, i.e., refer to its footholds and roots (see Driesens 2014). It is logical, then, to highlight the omnipresence of celebrities in our daily life - they are scattered across numerous social spheres and bubbles in dispersed fashion. Furthermore, to understand how modern celebrity culture operates, we ought to keep in mind that "celebrity becomes something a person does, rather than something a person is" (Marwick 2016: 334). The process of celebrification, i.e. the transformation of "ordinary" people into celebrities (Driesens 2013: 643), thus also needs to be examined.

The wider social context of celebrity culture, i.e., the conditions under which it comes to being, should likewise not be disregarded. Thus, research dedicated to the topic of celebrity encompassed the subjects of "media construction of reality" (Hromadžić 2013), personalization and intimization of the public sphere, commodification of everyday life, and other related processes that cut into the social tissue and eventually reflect on the life of every individual (see Rojek 2004: 13). All these processes serve as a catalyst and arena for the development of celebrity culture.

Undoubtedly, celebrity culture may also be observed through the lens of consumer capitalism (see Hromadžić 2010). Some authors see it as a substitute for God or transcendence in today's materialist reality and, in that sense, equivalent to religion and its previous function (see Rojek 2004: 51-99; Cashmore 2006: 250-255). It may also be understood as a byproduct of people's narcissistic self-obsession, since the public appears to experience (identify with) celebrities as ideal-embodiments of model authenticity and individuality (Cashmore 2006: 101-105).

More recent shifts in celebrity culture testify to the changes occurring in media content and practices (see Driesens 2013; Marwick 2016; Turner 2016). Today's celebrity culture has progressed a long way since the days when everything was broadcast through traditional media - press, radio, and television - as, ever since the turn of the century, the vitality of media culture has manifested itself in the growing popularity of converged, and then of new media. ${ }^{4}$ Furthermore, innovative communication technology has also left an important mark on the celebrity sphere. Although photography and facial images are still fundamental, interactivity is a huge innovation because it amplifies the effect on the receptive and perceptive apparatus of the audience and opens up new options in the development of commodified image, and commodified community, not only for the famous but also for "ordinary people".

The internet revolution in celebrity manufacture that took place during the 2000s, coupled with the transformation of modalities in which the audience follows them, has

4 For one possible typology of the media, which includes the categories of traditional, converged, and new media, see Zgrabljić-Rotar 2017. The author points out that the convergence of media "in the simplest understanding of communication discipline, was possible due to the merging of three platforms: broadcasting (radio and television), internet, and telecommunications" (op. cit.: 60) and that converged media "developed on the platform of internet [. . . but still keep the main features of mass media [...] where the form of communication is one towards many" (op. cit.: 63). 
resulted in new, changed profiles and scale of fame and public recognition. This primarily refers to the ascent of non-media individuals to "celebrity orbit", a process that led to certain transformations in the structure of celebrity culture. From that point on, on a conceptual level, a prefix "micro-" began to appear before the word "celebrity" as an indicator of differences between channels used by celebrities proper and micro-celebrities to gain and maintain fame/public recognition, and between the audience of the former and the fandom of the latter (see Gamson 2011: 1065-1067).

\section{MICRO-CELEBRITIES}

To understand contemporary celebrity culture, we must necessarily pay attention to the concept of micro-celebrity. The meaning of this notion is seemingly self-evident due to the prefix "micro-", which usually indicates the quantitative dimension of the second part of the word, but it is actually the qualitative aspect of the compound that is crucial for recognizing the distinction between celebrities and micro-celebrities (see Gamson 2011: 1067; Marwick 2016: 338).

This new type of celebrity, the product of the era of social networks and social media, does not have a massive audience nor is it widely recognized. Micro-celebrities, as a rule, have only limited groups of followers and are known only in a particular niche. The number of followers can vary quite extensively from one social media star to another, and these numbers are sometimes manipulated, i.e. artificially "inflated" to create a false sense of popularity. Although internet fame is difficult to measure reliably, if we applied Andy Warhol's prophecy that in the future "[...] everyone will be world-famous for 15 minutes" (see, e.g., Hromadžić 2010: 626 or Rojek 2012: 28) to the micro-celebrity phenomenon, we might paraphrase it to: "[I]n the future, everyone will be famous among their 15 followers" (Senft 2008: 25).

"Celebrity inflation" (Rojek 2012), i.e., the invasion of micro-celebrities into the sphere of celebrity, is caused by shifts in mediatization. Mediatization is a prerequisite for celebritization in general, a meta-process that involves not only technology but also organization, social institutions and practices (Driesens 2013: 650-651; see also Zgrabljić-Rotar 2017). The mediatization of culture is manifested in the increasingly pronounced influence of new media on both the construction of daily life and the most intimate dimensions of individuals' everyday existence.

5 There are many disputes related to the frequently emphasized thesis on the ever-more-active role of media consumers in celebrity culture. Turner's well known position on this topic, this "demotic turn", is his view that democratization in the sense of the "ascent of the ordinary" and empowered position of consumers in celebrity culture does not negate hierarchical and exclusivistic policies and strategies in that domain, primarily in the sphere of the media (Turner 2004: 82-86; 2015: 83-90). A similar critical line of thinking is followed by Helena Popović: "Alleged participation and inclusivity is another name for instrumentalization, exploitation, and manipulation of people by the media industry and advertisers" (Popović 2012: 40). 
In the age of the decentralization of celebrity production, when "anyone with a mobile device, tablet or laptop may become an internet celebrity", the aspects of celebritization are changing, and so are the channels of celebrification, i.e. the range of techniques and strategies available to individuals to reach their "micro-fame" (Marwick 2016: 334). In that context, micro-celebrity is a communicative practice, a performance of private self, a way of thinking of oneself as a celebrity (see Jerslev 2016: 5239), and it implies the rise of ordinary people through digital platforms and a bottom-up approach.

Such trends and practices narrow the gap between celebrities and their fans (Jerslev 2016: 5235). Creating intimacy with audience becomes especially important (Senft 2008: 26; Jerslev 2016: 5240), with emphasis on the "close and inclusive", "here-and-now" approach (Jerslev 2016: 5234).

\section{CELEBRITY CULTURE IN CROATIA}

Accepting that celebrity culture is associated with "turning the society into a market, a citizen into a consumer, public into private, informational and educational into commercial” (Hromadžić 2010: 617), and taking into account the fact that celebrities influence the lifestyle and values of a large number of people, I will now focus on the narratives about work in the Croatian celebrity culture. To that end, I will contextualize "how celebrity moulds the culture we live in, or the fields people are active in" (Driesens 2013: 653) in terms of Croatia and especially its media spaces, more specifically, on the status of the work of celebrities in these spaces.

My concept is close to Oliver Driesens' that there are cultural specificities of (sub) national celebrity cultures and that these may be explained as the result of the condensing of media cultures and translocal processes in particular geographic areas (Driesens 2014: 115-120). At the same time, I acknowledge the fact that today's "media landscape" in Croatia is "determined by programme characteristics of the so-called celebrity culture" (Hromadžić 2010: 619). In other words, I am aware of the overall tabloidization of media in Croatia, comparable to the one Maja Vukadinović (2013: 164-170) wrote about in the context of the Serbian transition period.

In Croatia, the trend of investing into one's own image or "self-branding" (see Hearn and Schoenhoff 2016: 200-202), which is typical of celebrities, has recently moved to social networks such as Facebook, Twitter, or Instagram. In this respect, practices that are common abroad are followed locally, albeit with some delay. Credit primarily belongs to brand new micro-celebrities who could be, due to their self-branding projects and advertising services on social media, categorized as social media influencers (see Khamis, Ang and Welling 2016). However, many true celebrities in Croatia also actively participate in this trend, for example the singers Severina, Jelena Rozga, and Tony Cetinski, or actor and TV-host Tarik Filipović, i.e. those who are already famous or at least well-known to 
a wider Croatian audience. All of them share a migratory quality in the sense of mobility within and across certain fields of activity (Driesens 2013: 645, 648-649).

In addition to influencers, the activities of bloggers, vloggers, and YouTubers have also contributed to the concentric spreading of celebrity culture in Croatia, with blog and video content mostly aimed at the younger population. To keep the loyalty of their followers, content creators strive to be knowledgeable about whatever they are advertising, or skilled at whatever they are engaged in. Finally, video-content production in Croatia occasionally features a variant of the "cam-girl", a well known phenomenon in the West often highlighted as a good example of DIY celebrity (see Turner 2004: 63-69; Senft 2008). In the Croatian context however, it largely appears to be about the modification of live video-streaming services to broadcast one's private and intimate life from the home to an interested audience, with the subsequent provision of sexually explicit homemade recordings to a wider public. ${ }^{6}$

Reality television, a phenomenon highly popular in Croatia in the last ten years, should likewise not be overlooked. The most successful contestants of the Big Brother (RTL TV) show, for example, draw explosive audience and public attention during their particular season, and then manage to keep it by maintaining a dispersed media presence. In a contingent discussion about the merits and achievements of these "celetoids", as Chris Rojek (2004: 20-23) initially termed the individuals destined to have a shorter expiry date and substantially shorter range of fame than traditional celebrities, a vital role might be played by media impresarios, cultural mediators involved in the creation and intermediation of their image. Although the rise of the internet and proliferation of social media present serious competition to reality television with respect to celebrity production and consumption, ${ }^{7}$ the re-runs of years-old shows in Croatia, and even the production of new ones, ${ }^{8}$ indicate that there is still substantial interest in this type of content and micro-celebrity figures.

\section{SCOPE, METHODS, AND LIMITS OF ANALYSIS}

This research analysis encompasses written material dedicated, to some degree at the least, to different aspects of work in Croatian celebrity culture, such as space, time, intensity, character, and value of that work, as published in newspapers and weeklies or posted on web portals in 2018 and the first half of 2019. It covers a relatively long period of intensified

6 Serbia also displays cases of starlets who gain popularity after their eroticized photographs or homemade videos appear in public, allegedly accidentally (Vukadinović 2013: 181-183).

7 Gamson sees reality television as a forerunner of internet in relation to the promotion of "ordinary" people, but the added value of the internet is that it allows audiences to develop their own potentials, and the role it plays in the manufacture of celebrities (Gamson 2011: 1064-1067).

8 Concerning this trend of commercial television programming in Croatia in 2019, see https://www. jutarnji.hr/kultura/film-i-tv/nikad-vise-realityja-na-domacim-televizijama-ove-godine-na-programimacak-osam-takvih-emisija-dolaze-i-novi-hit-su-ljubavni-showovi/8500187/, accessed July 12, 2019. 
media and public interest in the phenomenon of micro-celebrities, primarily "social media influencers". My intent was to cover narrative items on celebrities published in the widest range of traditional media possible, with a specific focus on the work of (micro-)celebrities in Croatia.

Although focusing on this narrow segment of mass media and converged media, social media was not disregarded (i.e., posts of celebrities and famous persons in Croatia and related reactions of their followers that were considered relevant to this topic were also included). However, given that these media tend to convey and analyze the most popular or engaging content from new media, they were somewhat filtered (see Volarević and Bebić 2013). Also, this research analysis includes the once crucial and still highly important medium - television. Part of the written material selected for the analysis reprocesses or comments on television pieces pertinent to the topic of celebrity.

In order to boost readership, two newspapers with relatively high circulation in Croatia, Jutarnji list and Večernji list, dedicate a sizeable portion of their total page space to entertainment. These newspapers regularly publish celebrity news and photos of celebrities abroad and in Croatia. Attention-grabbing details from their lives, be it professional or private, are reported on their websites and subjected to anonymous comments. Their professional plans, relationship toward work, and similar topics are a also a part of this type of content.

The situation is similar with magazines, especially those dedicated strictly to celebrity culture, such as the weeklies Story and Gloria. Numerous pieces published in these magazines invade the sphere of the private and bring less verifiable facts mostly collected from Facebook or Instagram profiles of the celebrities they write about. The intention of journalists and editors is to identify and create a "story" with the potential to pique the attention of readers and animate them into engagement; occasionally, they show a special interest in the jobs and work of famous figures.

These weeklies also regularly publish interviews with (micro-)celebrities. Of course, not even this genre can provide direct insight into the celebrities' professional and private lives, since the information reaching the readers has been mediated multiple times - from journalist questions and editorial decisions, to the interviewees' openness in disclosure of answers or appearance as their persona. For the needs of argumentation, I selected and analyzed parts of interviews in which (micro-)celebrities talked about their professional involvements and achievements.

Finally, many news, entertainment, and professional portals sporadically bring pieces on celebrity culture or particular celebrities. Their topics tend to seem trivial and unscrupulous, but at certain times nevertheless contain some related research, which then stimulates more serious discussions about particular features of celebrity culture. In any case, this type of content seems to attract readers of various profiles. For the purpose of argumentation, I analyzed such parts of articles and comments collected from these portals that were related to the work of celebrities. 


\section{NARRATIVES ABOUT THE WORK OF (MICRO-)CELEBRITIES IN CROATIA}

\section{CRITICAL AND AFFIRMATIVE NARRATIVE LINES}

In the written materials subject to this research analysis, two discernible and divergent lines of narrative appear concerning the work of (micro-)celebrities in Croatia. This is in agreement with Joshua Gamson's observation that "[C]ontemporary celebrity has been composed of two major, often competing narratives about the relation between celebrity status and merit" (Gamson 2011: 1063). In the analyzed sample these two lines of narrative intertwine and collide, complementing one another at the same time.

The first line of narrative criticizes the lifestyle of "celebrity" and the way celebrity culture operates in Croatia and, thus, foreshadows a sense of cultural and media decadence and the degradation (of value) of work in the Croatian society. More acutely, this line of narrative refuses to accept that the work of Croatian micro-celebrities should be treated as "honest" work, or "proper" work. It points to the pronounced aspect of leisure behind the signalled lifestyle and, ultimately, doubts a sustained living can be made independently through this particular occupation.

The second line of narrative positively evaluates the new forms of work gaining popularity in Croatian celebrity culture. It points out that conceptualizing one's life as a business, i.e. taking up self-entrepreneurship as (micro-)celebrities do, ${ }^{9}$ is both art and sacrifice. By surrendering their time and privacy to the media machinery, and the whims and needs of their fans, while managing to keep interest across time these individuals, (those who are successful) are seen to exhibit specific qualities and talents compounded by work and persistency. Potential exposure-dependent success, as lucrative as it may be, does not appear to guarantee security since competition is high (due to low access barriers) and new sensations and trends constantly emerging on the horizon.

\section{CONTROVERSIAL NEW VALUES OF WORK AND THE PROBLEMATIC OCCUPATION OF MEDIA SPACES}

The first line of narrative, which inverts the proverb Mr. Šprajc quoted his grandmother on - "no pain, no gain" into "gain without pain"10, may partly be explained by a differing

9 While Ella Dvornik conversed with Zoran Šprajc on the topic of "influencing” definitions, on RTL as noted above, she said among other things: "Sometimes I joke that I'm paid to live."

10 Beneath a photograph of her posing in a bathing suit, singer celebrity Severina Vučković wrote on her Instagram profile, in February 2015, her own expanded version of that proverb: "No gain without pain, no likes without tits and ass". This post, which obviously alludes to the "gain" celebrities strive for and "pain" they have to endure for it, was promptly relayed in numerous media.

See e.g. https://www.index.hr/magazin/clanak/Severina-Nema-kruha-bez-motike-nema-lajka-bezgolotinje/799351.aspx, accessed July 12, 2019. 
experience of work between generations that grew up in the socialist society of ex-Yugoslavia, and those who are growing up in post-socialist Croatia. In the last several decades, the Croatian labour market saw a dramatic increase in the share of the service sector at the expense of the once prioritized manufacturing sector (see e.g. Peračković 2010: 129-194). This trend has further accelerated in recent years, resulting in the near-total devastation of the industry, production plants, manufacturing companies, entire economic domains which had been the pillars of economic life at the local and national level (see, e.g., Potkonjak and Škokić 2013). Naturally, not all factors can be boiled down to the opposition between socialism and post-socialism, as the "network society" also brought changes on the global level. One way or another, "derisive reactions and a cynical tone mostly emanate from older generations, who still cannot fathom someone might be willing to pay people just for publically doing what everyone else already does - spending all their time on the internet or in front of the camera." 11

This first line of narrative aims its criticism primarily at those who leverage media platforms with the intention to use them not only for the promotion of others but also for self-branding, and extract capital by monetizing their own comfort and lifestyle. Behind these observations about the "emptiness" of their lives and "worthlessness" of their work mostly stand anonymous internet commentators on web-portals and social networks. Nevertheless, such criticism spreads through newspapers and is even expressed in interviews, thus becoming another public communication route that brings micro-celebrities into a defensive position: "People think influencers goof around or whatever, but we're into perfectly serious business. I've been in this line of work for five years now, it's hard work and good money." (Maša Zibar, vlogger). ${ }^{12}$

It is interesting that the work of influencers is negatively evaluated not only by numerous "ordinary citizens", i.e. those who do not appear in mass media and do not chase fame themselves, but also by some famous people who often appear in the media and see influencers as unfair competition in the "struggle" for media space.

Previously, you had to do something worthwhile first before getting media attention. Nowadays, complete non-entities get access to media. What does being an "influencer" even mean, what have these people done with their time except constantly taking selfies? Sadly, the smart and educated are no longer in demand - modern worth is measured by the number of social media followers. (Mirta Šurjak, TV host) ${ }^{13}$

11 http://novo.hr/influenceri-i-prikriveno-oglasavanje/, accessed July 12, 2019.

12 https://novac.jutarnji.hr/karijere/koliko-zaraduju-hrvatske-influencerice-slucajna-objava-cjenikapotvrdila-nagadanja/7690275/, accessed July 12, 2019.

13 https://www.24sata.hr/show/nisam-barbie-ali-trazim-kena-koji-ce-imati-hrabrosti-prici-mi-610960, accessed July 12, 2019. 
A second, affirmative line of narrative, which somewhat approximates the perspective of Millennials and their experience of new media on the global level, acknowledges the specific features and qualities of work performed by Croatian celebrities. It realizes that some professional activities of micro-celebrities pave the way to new business models that might revitalize the Croatian economy. The locus is generally on digital technology and their familiarity with that type of creativity, so the fact that "the general public simply doesn't understand how much work goes into putting out quality digital content" ${ }^{\text {"14 }}$ has been recognized as a cause of misunderstanding.

The necessary prerequisites for influencers to become the "masters of their advertising space" and "marketing powerhouses,"15 appear to be dedication and a professional approach to what they do. Among successful influencers, posting selfies on Instagram is levels above any amateurish activity. The notion of the "celebrity selfie" genre translates into taking complete control over the presentation of the private self. As much as it seems a good mode of establishing "digital intimacy" with fans on the one hand, it is clear on the other that direct communication with the audience through this channel cannot escape the dictate of commercialization (Jerslev and Mortensen 2016: 3-4, 12-13).

"Selfies" often require paying close attention to make-up and dressing, choosing natural or artificial light, and adjusting one's posture, then using apps and software to edit the photographs. They also require a fashion concept and consistency in presentation. The scope of all these activities may best be appreciated after having spent time with the protagonists themselves (Abidin 2016: 11-13). Specifically, it is "immaterial labour" (op. cit.: 2016: 10), which, looking from the outside, often (unjustly) appears undemanding.

To those who think "big deal, I could easily take tons of photos, too, sit around and do nothing making money", I'd advise to simply try doing it. They might be disappointed and surprised. Every single picture requires some amount of work, let alone the effort invested into a quality Instagram profile as a whole. Ok, it might not be drudgery like coal mining, but it's serious work and requires far more effort than apparent at first glance. (Nina Slišković Goleš, influencer) ${ }^{16}$

From an insider's point of view, it would appear the work put into photographs and settings by influencers is comparable to the work performed in creative industries (see Primorac 2012: 17-18). Although topics, such as fashion and travel, and the selfie genre take

14 https://www.netokracija.com/influenceri-sadrzaj-151129, accessed July 12, 2019.

15 http://privredni.hr/gospodari-oglasnog-prostora, accessed July 12, 2019.

16 https://www.index.hr/vijesti/clanak/moze-li-se-i-kod-nas-dobro-zivjeti-od-objavljivanja-svojih-slikana-instagramu/2017664.aspx, accessed July 12, 2019. 
the largest share among the Instagram influencers, business successes of micro-celebrities who developed their field of influence due to specific hobbies, such as cookery or gaming, testify to their effort, learning abilities, special knowledge and skills. In this case, videocontent and YouTube or written content and blogs are in the forefront.

The process a food blogger goes through is quite complex, it entails a lot of creativity. First, I need to test and develop a recipe. Then - after it's perfected - I'll take photos and/or make video instructions on how to prepare it, edit the photographs, edit the video, write the blog post and the recipe. Then I head onto social networks where I post the created content to Facebook, YouTube, and Instagram, along with the link to the blog. After that's done, I answer questions and reply to comments, interacting with the audience. (Matejka Buća, blogger) ${ }^{17}$

\section{PRECARITY AND FLEXIBILITY}

The affirmative line of narrative posits that the digital influencer occupation, or that of the blogger or YouTuber, requires creativity, talent and digital media skills, but it also carries the element of uncertainty typical for today's precarious work culture:

The problem is that it [influencing, blogging, etc.] is a profoundly unstable occupation, especially when it comes to income, because tomorrow can always bring new influencers who are more interesting, fresher, more appealing to the audience and its consumption tendencies, and the brands and businesses will happily switch between them. (Ivana Šulc, digital marketing manager) ${ }^{18}$

Competition is one aspect of risk in this occupation. Another is related to the rapidly shifting trends and fashion. All of these vectors stand in the way of achieving lasting stability. Thus, flexibility in this occupation field appears to be a necessity:

In my opinion, everything is transitory. We don't work 7 to 3 from the age of 18 to 65 at the same post anymore. People get tired doing the same thing year in year out, they seek change; more and more individuals venture outside their comfort zone and see good results, turn their hobbies into business or decide to pursue something completely new and succeed. I also think us YouTubers have an expiry date, though, and there's an inevitable time when our followers won't find

17 https://www.gloria.hr/ikona/matejka-buca-blog-me-itekako-usrecuje-a-najdraze-mi-je-kada-mi-pomaze-kcerkica-neva/7758567/, accessed July 12, 2019.

18 https://www.vecernji.hr/lifestyle/hrvatski-influenceri-otkrivaju-kako-su-uspjeli-u-zanimanju-kojegnedavno-nije-ni-bilo-1251798, accessed July 12, 2019. 
us as interesting anymore or, simply, we'll lose our own desire to keep doing it. $\left(\right.$ Nika Ilčić, YouTuber) ${ }^{19}$

The income of those on the media market fluctuates, there is no stable inflow of money. Influencers might also be paid for their work with exposure, instead. Holding professional involvements outside of the digital marketing sphere is therefore a prudent practice. Influencers understand that the popularity of specific social media is a variable category, and should be evaluated across time. As Anastazja Makjanić states, they rarely focus efforts exclusively in one direction:

I don't think influencers rely exclusively on their Instagram, or their blog, to support themselves. There's always a chance someone better or more interesting might come along, marketers are always hunting for the latest face. However, the situation in Croatia is getting better. Companies are realizing even Instagram posts require work and should be paid just like adds. ${ }^{20}$

\section{PRIVATE, PERSONAL, AUTHENTIC}

Traditionally high public interest in the private lives of the stars (Rojek 2012: 175-178) is something micro-celebrities take into account, and has been established as the norm. However, the loss of privacy may be viewed as the marketing of individual (micro-) celebrity capital. Investing time in self-production through social networking sites, which entails the substantial exposure of private life, represents a winning strategy for numerous micro-celebrities.

Nevertheless, this strategy does not appeal to everyone invested in the Croatian celebrity scene, and not everyone considers it a productive way to be. Those refusing to flood the public space with their private lives, in spite of it being an opportune thing to do, see it as an issue of self-respect and civility towards the audience. In the words of singer Petar Grašo:

I'm not the best for career advice on this, because that's not how I do it. When I'm not on stage, public life doesn't interest me. I'm not very active on social networks either, and I try not to burden people who enjoy my music with my private life, or waste their attention on trivial things. ${ }^{21}$

19 https://www.gloria.hr/fokus/zvjezdane-staze/najpopularnija-hrvatska-youtuberica-nika-ilcic-iza-mojekarijere-stoji-moja-mama/8067743/, accessed July 12, 2019.

20 https://www.index.hr/magazin/clanak/mislim-da-se-influenceri-ne-oslanjaju-samo-na-instagramkad-je-rijec-o-zaradi/2063492.aspx, accessed July 12, 2019.

21 Marija Lokas, Što kaže moja pjesma "Ostat ću uvik isti, u to se ne smi dirat." Studio, 10-16. 2. 2018. 
To note, micro-celebrities (just as traditional ones) strive for authenticity, which requires a constant deliberation of one's self-presentation in the (social) media. Social media personalities must appear attractive but also leverage their personality and, most importantly, leave the impression that this is the "genuine", non-airbrushed "them".

However, the professionalization of influencer activities in the direction of organized group production of internet content, i.e., the involvement of production teams and media experts (Usher 2018: 8-9), suggests that "self-presentation" is no longer necessarily a bottomup process. Although the possibility of successful emancipated functioning of influencers as individual entities on wealthier Western markets is an undecided matter, the situation on the Croatian market is quite lean. As one Croatian influencer explains, in general terms:

We do all these jobs in one - producer, presenter, camera person, editor. To shoot a campaign you generally require a makeup artist, set designer, stylist, photography director, editor, a person in charge of lighting, sometimes a sound recordist on the team. Currently, most Croatian influencers do it all themselves. (Maša Zibar) ${ }^{22}$

Another influencer describes her own, divergent work experience: "Behind each of my posts there are at least two people: the person taking the photographs and me. Sometimes, it's an entire team. On many occasions the process requires four or five people." (Marija Nikšić). ${ }^{23}$

Altogether, it is quite clear that the "authenticity" is performed for the followers, staged so to say, and delivered with the purpose of encouraging spending and consumption (Usher 2018: 9-14). And yet the facade of authenticity remains an essential element of this particular public image, though at times not evaluated properly by some clients:

No matter how much we emphasize the importance of authenticity and content quality, the truth is decisions often boil down to the numbers. I think longevitywise, influencers as well as the agencies should try and explain to their clients why numbers aren't the only thing we should be looking at. ${ }^{24}$

\section{THE MEDIA TRAJECTORY OF FAME}

Be as it may, from the perspective of micro-celebrity as a new economic phenomenon in the celebrity culture, audience size is something that cannot be disregarded. The expansion of one's influence represents a resource that can be further leveraged. As Anne Jerslev

22 https://www.gloria.hr/ikona/masa-zibar-na-pocetku-su-mi-se-svi-smijali-a-danas-imam-72-tisucepratitelja/7762887/, accessed July 12, 2019.

23 https://www.index.hr/magazin/clanak/njen-posao-iz-snova-poslovi-me-sami-nalaze-a-nitko-mi-nebi-platio-za-nerad/2061468.aspx, accessed July 12, 2019.

${ }^{24}$ https://www.netokracija.com/ladies-influencer-edition-izvjestaj-148066, accessed July 12, 2019. 
(2016: 5246-5248) points out, traditional celebrities and classic media follow different temporalities from those followed by micro-celebrities and social media, and she wonders whether keeping distance from the audience and making rare appearances in public are sustainable or valuable assets in today's media context.

It is interesting that mass media, especially television, is (in Croatia specifically) still unrivalled as means of support for the construction of the public persona of microcelebrities (see Usher 2018). Quite a large number of bloggers and YouTubers have accepted the opportunity to appear on, or distribute their content through television shows, media web platforms and weekly or newspaper interviews. Some parlayed their creator status into further business ventures. It is logical to assume the primary driver of these decisions was to achieve sustained and diversified media presence.

Thus, some well-known Croatian bloggers and influencers raised their visibility through competition TV shows, either as jury members or competitors. Their general performing affinity engaged the interest not only of already existing social media followers, but also tabloid and even journalistic media. On this type of involvement, a participant commented: "People keep asking why I agreed to do something that requires round-the-clock dedication, constant work, accessibility, setting everything else aside” (Sinja Kovač). ${ }^{25}$

\section{THE GAP BETWEEN THE REALITY SHOW GENRE AND SOCIAL REALITY IN CONTEMPORARY CROATIA}

The "star-making" trajectory of bloggers and influencers is different from that of the participants in "classic" reality shows, such as e.g. Big Brother. The rise of celetoid figures through the latter (reality shows) is indicative of the widespread inflation of fame and celebrity (see Rojek 2012: 161-172), which is why "becoming famous" is increasingly a diluted concept in terms of major achievement. However, it is easier to live and maintain the status of a "star" in post-developed economies of the West than it is in present-day Croatia. A TV critic for the weekly Studio based his review of the TV show Zvijezde pjevaju ("Singing with the Stars") on a cynical evaluation of the protagonists' long term prospects:

Not to sound harsh, but it's highly doubtful any of these sparks, these sparkles, even the occasional starlet who finds their way to the public stage would be capable of living off their stardom in the true manner of a star. However, the Croatian Television has money to spare, and so hyperbolic statements come naturally. ${ }^{26}$

\footnotetext{
25 https://www.tportal.hr/showtime/clanak/sonja-kovac-svi-me-pitaju-zasto-sam-pristala-sudjelovati-uovako-zahtjevnom-projektu-i-stavila-posao-i-putovanja-na-stranu-foto-20190319, accessed July 12, 2019.

26 Tomislav Čadež, Bogata produkcija, ali bezazlena i umivena. Studio, 16.-22. 3. 2019.
} 
The reality show as a form also comes under relentless criticism in its apparent undermining of the hard-established values of labour surviving from socialist times. Specifically, one columnist called out the TV Nova show Farma (The Farm) for doing exactly that by criticizing its format, content, and cast featuring a host of unsavoury characters. Few of the show participants had any ability or experience with farming, something they were not really expected to. Their work was reduced to the labour of being constantly watched, under commercial surveillance and the eye of the public (cf. Andrejevic 2002: 231). Moreover, the show was being produced while the real agricultural sector was suffering economic devastation in large swaths of the country:

Of the entire Croatian proletariat, of the entire relatively serious industry and strong agriculture, of all the workers and peasants standing in long lines at purple dawns in front of ironworks and agricultural cooperatives, exactly eighteen of them remained; and there they are, all eighteen of them, participating in a feebleminded TV show shot at a pseudo-agricultural estate near Zagreb. And they make quite a representative sample, including five or six cooks and waitresses and two or three retired veterans. For three months, under 24-hour video surveillance, they simulate a real life and real work, entertaining hundreds of thousands of historical losers whose real lives once looked like that, and who did real work under 24-hour surveillance. (Boris Dežulović) ${ }^{27}$

\section{BETWEEN AN ENGAGING HOBBY AND AN ENTIRE RANGE OF JOBS, FROM "TRADE OF THE FUTURE” TO "SURVIVAL STRATEGY"}

The critical narrative line emphasizes influencers' laconic approach to life and work, or at least its projection, their wasting of time on a perpetual life of apparent leisure, and perpetual celebration of consumerism. But from the affirmative point of view, the idea of seeing everything as a hobby and "living in the present" without worrying about business problems or the future makes sense, and is familiar even to very successful or grounded individuals. "Personally, I don't see it as a job so I'm not going to try and convince anyone of the opposite. For me, it's an awesome hobby to pursue while I'm in college" (Issabella Rakonić, fashion blogger). ${ }^{28}$

Interestingly enough, in addition to readily accepting many different jobs, (micro-) celebrities often resort to the demystification of their work in an attempt to remove the aura of specialness around them, their private life and the way they spend leisure time. For example, Saša Lozar, introduced as a musician, radio host, and TV show judge, said in an interview: "My day is not different from the day of any other working person. Trying to

27 https://www.portalnovosti.com/farmerski-manifest-1, accessed July 12, 2019.

$28 \mathrm{https} / /$ www.gloria.hr/ikona/isabella-rakonic-moda-je-moj-bijeg-iz-monotonog-zivota-studenticeprava/7762977/, accessed July 12, 2019. 
make a living, taking care of the family and career. The jobs vary but in principle everything is the same, so I don't think of myself as special or different in any way." 29

Still, being a social media influencer with clear business goals in the area of digital marketing is sometimes treated by the interested (professional) public as "a profession for the new era," ${ }^{30}$ with the potential of becoming the "trade of the future." ${ }^{1}$ To note, brands and companies are increasingly confident about this type of advertising. On the other hand, traditional celebrities find it harder and harder to keep up with this trend, and even when they do experience certain barriers, so they have no choice but to seek out collaborations with specialized companies.

In her role as a fashion ambassador, singer Indira [Levak] shot another campaign for the footwear company Planet Obuća's 2018 spring/summer season, and also tried her hand at shoe designing. Planet Obuća will offer new models for the spring season in the Star Collection, developed in collaboration with Indira. ${ }^{32}$

They tend to lack expertise in trendy fields and have little authority on the products they advertise, so they are not efficient in generating audience interest in a specific product, relatively speaking. Therefore, they prefer to monetize their fame by going into secondary businesses, mostly in fashion. Some also take up winemaking, start their own beauty line or design various accessories, like umbrellas. ${ }^{33}$

Moving away from their primary business and familiar professional landscape into "branching" projects may be interpreted in a variety of ways. Actor Enes Bešlagić described his side jobs and business ventures, including his co-ownership in a chocolate factory, as a "survival strategy". "It makes me happy and helps me put food on the table for my children. There's no shame in work, as long as it's honest work!"34

29 Klara Rožman, Kad mlad uđeš u brak, lakše se nosišs s lošim i više cijeniš dobre stvari. Studio, 12.-18. 5 . 2018.

30 https://zena.rtl.hr/clanak/poslovni_savjeti/zanimanje_novog_doba_influencer/24740, accessed July $12,2019$.

31 https://novac.jutarnji.hr/karijere/koliko-zaraduju-hrvatske-influencerice-slucajna-objava-cjenikapotvrdila-nagadanja/7690275/, accessed July 12, 2019.

32 Anon., Zna što žene vole. Story, 7. 3. 2018.

33 https://100posto.hr/scena/lana-jurcevic-bacila-se-na-ulje-majuska-na-vlastitu-memorabiliju-a-elladizajnirala-kisobrane, accessed July 12, 2019.

34 Klara Rožman, U showu 'Zvjezdice' više gnjave roditelji od djece. Svaki misli da mu je mali Ronaldo. Studio, 28. 4.-4. 5. 2018. 


\section{CONCLUDING REMARKS}

As Rojek states: "Nowadays, the high and the low mix easily in the washing machine of celebrity culture" (Rojek 2012: 10), and so do different categories and subcategories of celebrities mix in the "washing machine" of celebrity studies. Many shifting definitions and inconsistent typologies have appeared, reflecting on the present research concerning the two principal lines of narrative surrounding the work of (micro-)celebrities in Croatia.

(Micro-)celebrities analyzed in this text are a product of the extensive individualization of society, a phenomenon that is in some measure apparent in Croatia, too. Accordingly, the line of arguments circumvented the traditional perception that Croatian collectivistic culture "sprouts its own heroes", stars and celebrities. Left out were also specific celebrities such as the singer Marko Perković Thompson, who reach their status practically outside the media machinery and without exposing their private life, through "unplanned" bonding with populist sentiments (Pletenac 2016: 31, 38; cf. Duvnjak 2014).

Similarly, this research has not included the increasing propensity of Croatian politicians to communicate their views through social networks (Volarević and Bebić 2013: 62). By excluding from the analysis the new politicians who boost their image in a manner characteristic for social-media influencers, the concept of the "influencer" has been somewhat limited in scope, yet kept in line with the conceptualization used by recent research on micro-celebrities (Abidin 2016; Hearn and Schoenhoff 2016; Jerslev 2016; Khamis, Ang and Welling 2016).

The performed analysis of narratives illuminated the following significant findings about the work of Croatian celebrities:

Croatian micro-celebrities work primarily in the space of digital media, but show migratory potential across all areas of business and types of media, including television as a medium that helps them reach the widest possible audience. The transformation of television content in the past ten years or so (Kavka 2016) reflects positively on the opportunities for "ordinary people" to climb the Croatian celebrity ladder.

Just as in Western countries, the work of micro-celebrities in Croatia revolves around their personal life which becomes their business platform: the sphere of leisure cannot be separated from the sphere of work. But they do not see turning work into leisure and vice versa as a weakness or issue. For them, it rather turns out to be a luxury, and a resource in terms of commodifying their lifestyle. Leisure is highly valued when it comes to lifestyle commodification; this invokes an old idea from Thorstein Veblen's theory of the leisure class: that flaunting one's own leisure time and restraining from physical, or any other tangible work, is a mark of social status (Veblen 2008: 99-121).

From the micro-celebrity's standpoint, the motto that "life becomes the most precious capital” (Gorz 2015: 18) may be exploited successfully, but André Gorz dissects the premises surrounding "the arrival of self-entrepreneurs" and their "life as a business" from a wider angle. By critically describing the metamorphosis of work in the age of digital 
capitalism, he interprets these premises as a problematic subjugation of human life to the rule of economic capital (op. cit.: 16-20).

Although the work never stops, it is - according to the testimonies of the microcelebrities - not tedious but aligned with their personal affinities and needs. Having successfully captured the attention of their target audience (comp. Marwick 2016: 343-346), they must be in permanent communication with their followers and fans, they have to be present, be "here and now", be part of their followers' lives and make the followers feel as if they are part of theirs. Be accessible, then.

In the beauty and health niches, micro-celebrities continuously work on their appearance; their work includes taking care of their body, style, presentation, fitness etc. for extended periods; appearing in these parameters similar to modelling work (Wissinger 2007: 254-256). The effort of micro-celebrities thus goes beyond emotional labour, i.e. management of emotions understood as a conscious adaptation to what the expectations of the audience command (Hochschild 1979). It also requires energy spent on the body's commodification, which in turn incites emotions as a result of erotic stimulation or idealistic presentation. Involvements also frequently imply small productive units, ad hoc projects, networks and streaming, invested in communication and social relations. It is, therefore, affective labour in one sense and immaterial labour in the other (Lazzarato 1996), both the forms of labour that are difficult to recognize (Wissinger 2007: 251-254).

Although economic parameters often show that micro-celebrities are into "hope labour", which could revitalize the economy and, as paradigms change, stabilize it on new foundations (Hearn and Schoenhoff 2016: 194), the sheer scope and nature of prejudice against it indicates that the opaqueness of their work is what undermines it the most. Additionally, there is no doubt that the contamination of their work with different aspects of consumerism contributes to this image of tackiness. What makes Croatian society distinctive is the small size of its celebrity capital market, yet - as is the case in the West - "identification with stars is most obvious in the area of spending" (Vukadinović 2013: 189), where the consumers' "value orientation with a salient hedonistic dimension" (op. cit.: 188) is shaped primarily by new "micro-"celebrities.

Besides the domination of readily available entertainment and spectacle, i.e. the mediasupported promotion of consumerist lifestyle, the problem lies in the systematic devaluation of the (far more) material labour in many areas of social interest: the price of such labour is kept low, working conditions are poor, labour rights are limited. The above makes a broader appreciation of the specific labour of (micro-)celebrities in Croatia very unlikely. Further, the current socially fraught period of mass emigration from Croatia ${ }^{35}$ indirectly affects the public perception of (micro-)celebrities and their projection of easy living. It

35 The Croatian Bureau of Statistics data on external and internal migration of population in the Republic of Croatia from 2008 to 2017 (https://www.dzs.hr/Hrv_Eng/publication/2018/07-01-02_01_2018. $\mathrm{htm}$ ) corroborate the thesis of constantly increasing numbers of people leaving the country. For the impact of increased migration after Croatia had joined the Europan Union in 2013 on the Croatian labor market and economy, see Župarić Iljić 2016. 
is, therefore, even more important to consider the context when pondering Cashmore's observation that celebrities "don't exactly sell their labour or expertise, so much as their presence" and appearance in the media (see Cashmore 2006: 5-6), i.e., to understand the specific validity of such perceptions given the social and media situation in Croatia.

\section{REFERENCES}

Abidin, Crystal. 2016. “Aren't These Just Young, Rich Women Doing Vain Things Online?”: Influencer Selfies as Subversive Frivolity. Social Media + Society 2 (2): 1-17.DOI: https://doi.org/10.1177/2056305116641342.

Andrejevic, Mark. 2002. The Work of Being Watched: Interactive Media and the Exploitation of SelfDisclosure. Critical Studies in Media Communication 19 (2): 230-238.

Cashmore, Ellis. 2006. Celebrity/Culture. London and New York: Routledge.

Čolović, Ivan. 2016. Paths of Glory: How Marginal People Force the Nation's Attention on Themselves. Traditiones 45 (1): 21-29. DOI: https://doi.org/10.3986/Traditio2016450102.

Driesens, Olivier. 2013. The Celebritization of Society and Culture: Understanding the Structural Dynamics of Celebrity Culture. International Journal of Cultural Studies 16 (6): 641-657. DOI: https://doi. org $/ 10.1177 / 1367877912459140$.

Driesens, Olivier. 2014. Theorizing Celebrity Cultures: Thickenings of Media Cultures and the Role of Cultural (Working) Memory. Communications 39 (2): 109-127. DOI: https://doi.org/10.1515/ commun-2014-0008.

Duvnjak, Neven. 2014. Marko Perković Thompson: National Hero or Croatia’s Troublemaker? In: István Povedák (ed.), Heroes and Celebrities in Central and Eastern Europe. Szeged: Department of Ethnology and Cultural Anthropology, 186-198.

Gamson, Joshua. 2011. The Unwatched Life is Not Worth Living: The Elevation of the Ordinary in Celebrity Culture. Publications of the Modern Language Association of America 126 (4): 1061-1069.

Gorz, André. 2015 (2003). Nematerijalni rad: Spoznaja, vrijednost i kapital. Zagreb: Tim Press.

Hearn, Allison, and Stephanie Schoenhoff. 2016. From Celebrity to Influencer. In: P. D. Marshall (ed.), Companion to Celebrity. Chichester: Wiley Blackwell, 194-212.

Hochschild, Arlie Russell. 1979. Emotion Work, Feeling Rules, and Social Structures. The American Journal of Sociology 885 (3): 551-575.

Hromadžić, Hajrudin. 2010. Mediji i spektakularizacija društvenog svijeta: Masmedijska produkcija 'kulture slavnih'. Filozofska istraživanja 30 (4): 617-627.

Hromadžić, Hajrudin. 2013. Politika, društvo spektakla i medijska konstrukcija realnosti. Politička misao 50 (2): 60-74.

Jerslev, Anne, and Mette Mortensen. 2015. What is the Self in Celebrity Selfie?: Celebrification, Phatic Communication and Performativity. Celebrity Studies 7 (2): 1-15.

Jerslev, Anne. 2016. In the Time of the Microcelebrity: Celebrification and the YouTuber Zoella. International Journal of Communication 10: 5233-5251.

Khamis, Susie, Lawrence Ang, and Raymond Welling. 2016. Self Branding, Micro Celebrity and the Rise of Social Media Influencers. Celebrity Studies 8 (2): 191-208. DOI: https://doi.org/10.1080/193 92397.2016.1218292. 
Lazzarato, Maurizio. 1996. 'Immaterial Labor'. In: Paolo Virno and Michael Hardt (eds.), Radical Thoughts in Italy: A Potential Politics. Minneapolis: University of Minnesota Press, 132-147.

Marwick, Alice E. 2016. "You May Know Me from You-Tube”: (Micro-)Celebrity in Social Media. In: P. D. Marshall (ed.), Companion to Celebrity. Chichester: Wiley Blackwell, 333-350.

Peračković, Krešimir. 2010. [Za]što raditi u postindustrijskom društvu?: Promjene u društvenoj podjeli rada na početku 21. stoljeća. Zagreb: Institut društvenih znanosti 'Ivo Pilar'.

Pletenac, Tomislav. 2016. Accidental Celebrity?: Constructing Fame in Postwar Croatia. Traditiones 45 (1): 31-46. DOI: https://doi.org/10.3986/Traditio2016450103.

Podjed, Dan. 2014. Slovenian Bubble Celebrities. Establishing and Maintaining Celebrity Status on the Internet. In: István Povedák (ed.), Heroes and Celebrities in Central and Eastern Europe. Szeged: Department of Ethnology and Cultural Anthropology, 206-226.

Podjed, Dan. 2016. “We Don't Need Another Hero!” The Importance of Celebrities in the Post-Truth Era. Traditiones 45 (1): 7-20. DOI: https://doi.org/10.3986/Traditio2016450101.

Popović, Helena. 2012. Popularni televizijski žanrovi kao refleksija suvremenog društva. Holon 2 (3): 18-43.

Povedák, István. 2014. Introduction: From Heroes to Celebrities: Problems of Definition and Potential Solutions. In: István Povedák (ed.), Heroes and Celebrities in Central and Eastern Europe. Szeged: Department of Ethnology and Cultural Anthropology, 7-17.

Primorac, Jaka. 2012. Od nesigurnosti do nesigurnosti: Rad i zaposlenost u kulturnim i kreativnim industrijama. Revija za sociologiju 42 (1): 5-30. DOI: https://doi.org/10.5613/rzs.42.1.1.

Rojek, Chris. 2004. Celebrity. London: Reaktionbooks.

Rojek, Chris. 2012. Fame Attack: The Inflation of Celebrities and Its Consequences. London and New York: Bloomsbury Academic.

Senft, Theresa M. 2008. Camgirls: Celebrity and Community in the Age of Social Networks. New York: Peter Lang.

Škokić, Tea, and Sanja Potkonjak. 2013. "In the World of Iron and Steel”: On the Etnography of Work, Unemployment and Hope. Narodna umjetnost 50 (1): 74-95.

Turner, Graeme. 2004. Understanding Celebrity. London, Thousand Oaks and New Delhi: Sage Publications.

Turner, Graeme. 2016. Celebrity, Participation and the Public. In: P. D. Marshall (ed.), Companion to Celebrity. Chichester: Wiley Blackwell, 83-97.

Usher, Bethany. 2018. Rethinking Microcelebrity: Key Points in Practice, Performance and Purpose. Celebrity Studies (2018): 1-18. DOI: https://doi.org/10.1080/19392397.2018.1536558.

Veblen, Torsten. 2008 (1899). Teorija dokoličarske klase. Novi Sad: Mediterran Publishing.

Volarević, Marija, and Domagoj Bebić. 2013. Društvene mreže kao izvor vijesti u najgledanijim središnjim informativnim emisijama u Hrvatskoj. Medijske studije 4 (8): 60-75.

Vukadinović, Maja. 2013. Zvezde supermarketkulture: Medijska slava upotrošačkom društvu. Beograd: Clio.

Wissinger, Elizabeth. 2007. Modelling a Way of Life: Immaterial and Affective Labour in the Fashion Modelling Industry. Ephemera 7 (1): 250-269.

Zgrabljić-Rotar, Nada. 2017. Novi mediji digitalnog doba. In: Ljubica Josić (ed.), Informacijska tehnologija i mediji. Zagreb: Hrvatski studiji, 57-64.

Župarić Iljić, Drago. 2016. Iseljavanje iz Republike Hrvatske nakon ulaska u Europsku uniju / Emigration from the Republic of Croatia after the Accession to the European Union. Zagreb: Friedrich Ebert Stiftung. 


\section{PRIPOVEDI O DELU V HRVAŠKI KULTURI SLAVNIH}

Prispevek temelji na raziskavi pripovedi o delu »mikro-slavnih« oseb oz. vplivnežev na Hrvaškem. Raziskava analizira besedila, objavljena $v$ časopisih, tednikih in na spletnih portalih v letu 2018 ter prvi polovici leta 2019. Predmet so različni vidiki in pogledi na delo v hrvaški kulturi slavnih: prostor, čas, intenzivnost, pomen, navsezadnje vrednost. Posebna pozornost je posvečena mikro-slavnim, za katere je značilno, da nagovarjajo specifične ciljne skupine; vsekakor pa do statusa slave in medijske prepoznavnosti prihajajo po drugačni poti, kot je bilo značilno $z a$ "klasične" slavne osebnosti. S pojavom resničnostne televizije in z vsesplošno dostopnostjo interneta je "običajnim ljudem "naenkrat omogočen dostop do širše javnosti in prepoznavnosti. Analiza besedil pokaže, da medijske pripovedi, ki v veliki meri spremljajo delo protagonistov te digitalno razširjene kulture slavnih na Hrvaškem, po eni strani kažejo na skeptičen odnos do življenjskega sloga vplivnežev, po drugi pa pozitivno vrednotijo nove oblike nematerialnega dela in samopodjetništva, ki jih predstavlja takšna dejavnost.

Dr. Ozren Biti, Research Fellow

Institute of Ethnology and Folklore Studies

Šubićeva 42, HR - 10000 Zagreb, Croatia, ozren@ief.hr

This contribution was fully supported by the Croatian Science Foundation under the project Transformation of Work in Post-transitional Croatia (IP-2016-06-7388). 